Doru POP

\title{
On the Dialectical Value of the Science of Mickey Mouse or the Return of the Negation of the Negation in Cinema Studies
}

\begin{abstract}
Many authors have announced the death of theory or the end of criticism, while others tried in recent years to reinvigorate Critical Theory or Marxism, in an effort to adapt them to the realities of the XXI-st century. There are several lines of questioning here, the first is if the analytical principles developed during the XIX-th century are still practical. While a 'second generation' of critical theorists provided innovative reflections in the contemporary theoretical inquiry and advanced multiple solutions and conceptual renewals of the field, the most problematic issues about theory remain unsolved. This is visible in the intellectual conflict between the proponents of post-theory and the followers of Grand Theory. Using the framework of film studies, this paper raises some of the most difficult questions when it comes to ideological, social and political critique, and more importantly the problem is its methodological validity. Also, have the social sciences exhausted all the resources of critical thinking, is this a moment of utmost exhaustion the dialectical criticism? This study opens as an overview of the most important debates about Critical Theory and critical thinking today, and offers a final and personal response for how the critical method can still be practiced. By proposing a new dialectical approach for interpreting recent cinematic productions the author advances the concept of fluid dialectics. Recovering the mechanisms of dialectical approaches from Hegel to Marx and Lacan this paper is making a modest suggestion, that of the return to powers of the dialectical method
\end{abstract} and the magic of the negation of negation. To the announced "death of theory" the answer here is the revival of the debate about the force of dialectics.

Keywords: Marxism, cinema studies, Critical Theory, posttheory, dialectical method, negation of negation

\section{Doru POP}

Doctoral School of Theater and Film

Babeș-Bolyai University

doru.pop@ubbcluj.ro

EKPHRASIS, $1 / 2018$

Several of years ago, Margaret Hodge, the British Minister for Higher Education, publicly criticized many academic institutions in the UK, dismissively describing them as offering too many "Mickey Mouse" courses. Some

Aftermaths of Critical Theory

pp. $36-65$

DOI:10.24193/ekphrasis.19.4

Published First Online: 2018/06/20 
"serious" scientists joined the chorus of disgruntled researchers, calling for the immediate cancellation of the financing for such "ephemeral" studies (Shepherd 2010). The age old argument was that the "fundamental sciences" must receive financial support, since they alone provide real knowledge, while the programs which offered their students the so-called "Mickey Mouse degrees" should be shut down. The contradiction between the "soft" and the "hard" sciences remains unsolvable when pejoratively labels like the "science of Mickey Mouse" is placed on the humanities. Considered to be lacking any rigorous methodologies, denounced for their subjective dimensions and defamed for being excessively theoretical, several disciplines were refused the right to be defined as "science". Of course, the argument for that segregation was pragmatic, they apparently provide no tangible results, no economic benefits can be demonstrated, no transformations in the overall prosperity of society.

In the case of film, media and television studies and many other fields related to cultural and pop culture research, these negative attributes were aggravated by the internal crisis of the humanities. The often announced "decline of humanities" was accompanied by radical announcement within the field, claiming that critical theory "died away long ago" (Latour 248). Several books added to the idea that "theory is dead", and many academics quickly reached to the conclusion that we in a posttheory, or in an after-theory moment. The atrophy of critical theory, manifesting in the last decade in North American academic environment, was accentuated by the apparent sensation that the political relevance of social criticism has reached a stage of total irrelevance (Wexler, vii). Researchers preoccupied with theory were accused of Leftist political inclinations and Marxist radicalism, their approaches were by now considered revolute. Neoliberalism was triumphing everywhere and there was no need for anymore critical discussions. As we can observe in our own societies, the crises of capitalism are not over, and neither did the internal antagonisms of the capital vanish overnight.

Many questioned the future of academia and suggested that universities should be exclusively connected to entrepreneurial values. The higher education institutions no longer needed to be clusters of critical thinking, they must be transformed by the triumphant ideology of capitalism into pragmatic enterprises. Unfortunately it appears that our post-industrial society, driven by social media interactions has no need for more citizens who can think critically and who would use their reasoning capacities to understand ideas. In the "digital age", when a smartphone with broadband wi-fi connection is enough to be an intellectual, critical thinking seems an impractical skill. Instead we have a global dictatorship of fake news, the widespread of mindless political tweets and the domination of abominable stupidities and pseudo-scientific beliefs.

So why would we need critical inquiry? One of the optimistic solutions was provided by Martha Nussbaum's (2016) simple and convincing arguments that democracy needs humanities for its own benefit. We still need the distrust against 
authoritative opinions, the skepticism towards pre-established ideas and, more importantly, the fostering of inquisitive minds, when it comes to fake and false arguments. And the instrument for dissenting and contradicting reasoning is to be found in what Nussbaum described as "Socratic abilities" (48), in fact a mode of thinking that could prevent the degradation of our democracies. We need to return to the foundational nature of the Socratic thinking, however we also must realize that the critical approaches are even more relevant when looking at the worrying directions in which contemporary global politics seem to be steering our world. Without critical thinking intolerance is wide-spreading, hate speech is cultivated freely and our societies are leaning towards illiberal solutions.

\section{The Game of Theories.}

\section{Entering the Bloodless Wars of Film Critics}

Another vulnerability of humanities, extremely visible in film theory and cinema studies, is the academic squabble. The competing "theories" in film studies discredit each other, which is quite ironic for a field that has not developed an authentic theory of its own. While there is a plethora of academics and critics who mimic various philosophical meta-discourses (as is the case with the phenomenology of cinema) or borrow the jargon of critical theories, most of them are aggregated into what Peters, Olssen and Lankshear (2003) described as a "bogus" academic culture. These intellectual coteries, composed of film professors and their associate researchers, claim to perform innovative studies in which theys actually regurgitate ideas and pour out half digested theories, recirculating the same commentaries. The resulting effect is the commodification and caricaturization of philosophical assumptions (Peters, Olssen and Lankshear 1-2).

Although they have no theory of their own, the specialists in the field of film studies are positioned in separated lines along two broad theoretical approaches. Simplified here in order to make a better argument, the long and complex evolution of cinema studies is forced apart by the conflict between two major theoretical traditions. The first, rooted in the Marxist thinking and later identified as the "Grand Theory", and its contenders, advancing the so-called Post-Theory solution. The supporters of both of these approaches try to demonstrate that their "theory" is better, throwing the anathema on their opponents. Whether or not psychoanalysis precedes cognitivism, if formalism is more relevant than deconstructivism, or if poetics and stylistics have one major advantage on semiotics, it remains to be settled.

Some of the most abrasive debates were between David Bordwell, who made dismissive comments against critical theory, and Slavoj Žižek. This intellectual conflict shows that there is no dialogue between the cognitivist post-theory and the followers of Grand Theory, mostly because of their different biases. At the other end of this antagonistic spectrum are authors like David Rodowick (2014), who tried to substitute the eulogies of critical theory with his own "elegy for theory", by accepting 
the "problematic" dimensions of theory, yet optimistically believing in the return of film studies to the fundamental philosophical theories. Rodowick's optimism even allows him to claim that somehow movies could fuel the revival of theories and, more unlikely, to provide a synthesis between opposing views.

David Bordwell, who used the concept of "Grand Theory" as his own boxing bag, remains one of the most adamant critics of what he coagulated under a single conceptual unit as the "continental" theories. Inventing the stigmatizing label of "SLAB theory", this film historian vehemently condemned "the plague of theory" in film studies, identifying the nefarious effect of "Saussurean Semiotics, Lacanian Psychoanalysis, Althusserian Marxism and Barthesian textual theory" ('Historial Poetics of Cinema' 385-392). Applying the reprobate acronym SLAB and disparangly calling it "provincial" and a way of "not knowing" things, Bordwell waged a scholarly war for decades against his declared enemy - the "evil triumvirate" of Marx, Freud and Saussure). Labelling these approaches as "symptomatic interpretations" or "symptomatic criticism", legitimized only by their appeal to "theory" (Making Meaning 104), he positively charges his own "poetics" as systematic, while the "SLAB" researchers are only practicing "doctrinal abstraction". As I pointed out before, Bordwell's criticism is correct at a certain level, as he exposes the limitations of academic mimetism, but unfortunately it remains misdirected.

Many of the arguments used by Bordwell are part of the age old attacks against the much feared influences of Marxism on the "lumpen-intelligentsia" dwelling in the Western academic environments. Many others already announced the "poverty" of Marxist theory, among them E. P. Thompson, one of the most lucid critics of Marx, without minimizing the method of the German philosopher. For Bordwell, on the other hand, the defense of formalism or historicism leads to reducing all other theoretical approaches to being simple "protocols", "routines of reasoning" (18). Depleted of relevance, refused their status of real methods, with their applied results deemed as irrelevant, these theories are not criticized, but chastised. Always labelling his opponents as "doctrine driven", this author has an extreme disregard for the "New Film Theory", which is never concealed. The American film professor hurriedly rejects any validity for the critical observations from any study developed under the influence of Lacan, or from what he pejoratively identifies as "leftist" or "culturalist". The drive to denounce the influences of the Frankfurt School or the "Parisian ideas", comes oftentimes to Bordwell with a blindness for his own parochialism. This is explicit when he suggests Chomsky's theories and the generative grammar as a competing alternative against linguistic structuralism, omitting that Chomsky is himself an ideology critic.

The effort of "liberating" film criticism from the supposed captivity imposed on the academics who "ape" Marx and Engels was joined by Noël Carroll, riding the same horse as Bordwell in their crusade against the "Grand Theory". This came naturally, since in his others works Carroll also denounced the "negative triad" 
disrupting film studies, psychoanalytic interpretation, semiotics and Marxism, or what he identified as the "Psycho-Semiotic-Marxist" interpretations. Developing his own criticizing against the integration of Lacanian concepts into film analysis language, the philosopher of art proposed following other types of engagements with movies. Based on narration theories and storytelling structures, the manifestations of the cinematic were supposedly more relevant at their cognitive levels (Making Meaning 210). Later, in the collective volume edited by Carroll and Bordwell (1996), these supporters of cognitivist approaches promised a new set of methods who would be able to "reconstruct film studies". An while Bordwell self-labelled his approach either as constructivist or cognitivist, in fact this is a neo-formalist paradigm, as acknowledged by Kristin Thompson. The future of post-theory in film studies, Bordwell believed, rested in the "golden middle" of scholars practicing in-depth inquiries, doing the kind of research that would "endure" (29-30). For Carroll, on the other hand, "Theory" has simply "run out of gas", if it is not already dead (1996 38). Thus the only way to provide a diversification of disciplinary approaches would be to replace it with film theorizing which could allow a methodological pluralism (63).

Bordwell and his supporters never ceased to pejoratively use the "Grand Theory" formula as the grand scare of film theorizing, while insisting that the "Grand Theories" used in film interpretation and film studies have reached the end of their relevance. Their attacks, which are by now raging for decades, can be considered invalid if we were to take into consideration the fact that their rival frameworks are not dying out. More importantly, the alternative approaches supported and practiced by Bordwell himself, which were presented as "robust" and promising, did not provide more than a couple of books about film style and several historical overviews on various cinemas. While Lacanian psychoanalysis or the various forms of Marxist interpretations and other derivative doctrines were dismissed as "ethereal speculations" (xiii), the truth of the matter remains that Bordwell and Carroll advocated cognitivism with the same pathos as those authors they exposed as promoters of a ideologically flawed studies.

Looking back at these premonitions it is fair to say that the post-theory hypothesis was not bringing any relevantly innovative research, except replicating the same positivist evaluations that always existed. Bordwell's formalist framework, in which criticism must be practical (Making Meaning xii), resulted with film criticism practiced as constructive explanations, based on series of conventional examples. This pragmatism prevents in fact the innovation, while most of the truly remarkable studies in film research are based not on the abandonment of "interpretative" practices, rather on exploring the intricacies which link cinema with the intellectual tradition of social criticism.

I also must point out that the two supporters of post-theory mentioned make several conceptual misinterpretations, and two are very important for my own arguments. The first and foremost is their claim that there is a cohesive "Theory", a coherent effort to "explain everything", otherwise known as a "Grand Narrative". 
In fact, as elaborated by the study developed by Thomas McCarthy (1991), there is a secondary philosophical debate which splits the field of Critical Theory between another two major and opposing "theories" - the first based on the traditions of the Frankfurt School and the other pragmatic. And, although many critical theories have their theoretical foundations in the philosophy of Karl Marx, the reality is that not all the Marxists would agree on the same methodologies, nor would they practice the same method, or even define their concepts in unison. The best example is provided by the much blamed Althusser, who claimed he was reviving Marxist thinking and pretended to recuperate the resources of dialectical Marxism (215-216). In fact Althusser rejected one of the cornerstones of Marxist method, the negation of the negation in his outspoken demand for a "Marxist anti-humanism". Althusser wanted to "decontaminate" Marxism from the influences of Hegel or Feuerbach, in an impossible effort to separate political practice from the theoretical practice. Wishing to free Marx from his apparent utopianism, the French theorist attempted to "free" Marx from his Hegelianism.

More recently other authors, like Wilkerson and Paris (2001), proposed the development of a "New Critical Theory", based on Marcuse rather than on Adorno and Horkheimer, in an attempt to be more embracing to race theory, feminism and postmodernism, again at the expense of Hegel and Marx (3). These are only a couple of examples showing that the simplistic idea about a "Theory" which is functional and purposefully built is inconsistent.

The second error, previously elucidated by Slavoj Žižek when discussing other issues generated by post-theory (2009), is given by the fact that their perspective is based on misunderstanding the functions of dialectics. Clearly the paradoxical dimensions of dialectical thinking are sometimes hard to grasp and going beyond the simplistic contradictions between ideas is not an easy task. The Slovenian critical theorist developed his own arguments in this direction when he elaborated on the notion of parallax gaps (2006), showing how important it is to go beyond the naive understanding of dialectics. This inaccuracy is illustrated by Carroll, who in his defense positions in favor of post-theory appears to be more nuanced than his co-editor. Nevertheless, while Carroll is less dismissive, he is nonetheless more trivializing. Not only vulgarizing the intentions of Marxist criticism, but completely misusing the notion and function of dialectics. When Bordwell reiterated his attacks on Žižek's approach to cinema, asserting that is was non-dialectical (2005), he clearly recuperated the understanding of dialectics from Carroll's previous intervention. These interventions allow us to distinguish once more between the primitive meaning of dialectical practices, which are no better that sophistries and conversational contradictions, and the actual critique.

As I will try develop in my own argumentation, the distinction between the dialectical thought (or thinking) and the dialectical method is extremely important. As Adorno acknowledged, when building on the thinking of Hegel and Marx, the 
ability to use dialectics as a tool for identifying contradictions is not enough. We need to understand dialectics as as a "protest against mythology" (Adorno 1973 56); or to simplify the reasoning, it is a refusal of all false ideas. Only as a rejection of dogmas, biases and other forms of pre-established thinking the dialectic approach could help us in blocking fake assumptions and undisputed concepts.

\section{Critical theory at the borders of hypocritical criticism}

Before moving forward to dealing with the intricacies of the dialectical method we need to stop for a moment and accept the possible validity of the adversity pitted against the critical dimensions of theory. We cannot avoid the reality of the criticism of criticism, that is exposing the empty manifestations of theoretical debate as a "coterie critique". Practiced in many academic circles, such philistine behaviors, exposed already by Marx, display the undesirable limitations of humanities. A certain dismissal of the approaches solely based on "French theories" can be justifiable when applied to contexts in which every faculty speaks the same lingo, every paper reaches the same conclusions and each new Ph.D. student provides the same answers for any question.

Nevertheless, it was also a French theorist who pointed out that criticism must recover from its transcendental (read unworkable) dimensions and become actual. Michel Foucault, in his 1978 Sorbonne conference, discussed this trend as a result of a particular Kantian heritage. For the French critic the solution was a reactivated "critical attitude", which has to be based on historical realities. To be critical is a mode of approaching contemporary events, thus not every criticism has power. Without contesting, denouncing and disagreeing there is no overcoming of the petty criticasters who repeat cliches and juggle with citations and concepts they do not fully understand.

While some describe the development of cultural studies within the arts and humanities as already reaching a "crisis of criticism", others ask for a return of criticism. Some claim, as in the case of Ronan McDonald (2009) who decried "the death of the critic" by arguing that it was induced by social and political judgements, that serious criticism must be again aesthetically valid. The opposing view comes from Bruno Latour's arguments (2004), who suggested that the "critique" has lost its momentum, because of this lack of political force. Before asking if the "end of critique" is really here, the academic questioning seems doomed to repeat the same ideas over and over, raising again and again the same questions. This is where Latour identified the loss of power in academic thinking.This is the stand point from which he demanded a renewal of the critical mind. He proposed the abandoning of the disabling forms of empty critique and following a more radical path, the only one able to address the new threats in society, politics and culture.

The basis of these arguments was closely investigated by Reinhart Koselleck (1998), who properly placed the birth of modern critique in the moral criteria on which the 
European bourgeois philosophy was built upon. Criticism was transformed into a critical method, an intellectual exercise that swept across all disciplines, from Biblical hermeneutics to art evaluation, during the Enlightenment. The "proper" critique was represented for a long time by a particular form of reasoning, based on the legitimacy of the morally just thinking (10), based on the faith that rationality has illuminating force. Koselleck uncovers that this is a "process of criticism" which transformed the critical evaluation into critical hypocrisy. The "age of criticism" made possible various formulas of criticizing, all escalating to a point when the critique became petrified.

Today, as Peter Sloterdijk appropriately observed, we are faced with the "aftermath of critique", a cultural time when cynical thinking has replaced critical thinking. The critics became "functionaries of criticism" and cynicism is manifesting as an enlightened form of the false consciousness. Sloterdijk also identifies a solution in "the seed" of all Critical Theory approaches, that is Walter Benjamin's critical micrology, the ability for extreme closeness in the interpretative process (Sloterdijk xxxiii). My own method is following a similar path, by transforming the apparently minor manifestations into a basis for complex interpretations.

Since not every form of criticism is critical, and not every theorizing provides a coherent theoretical support, the basic Freudian discontent (Ubenhagen) has to become a critical way of thinking. My understanding of the critical thinkers follows Horkheimer's definitions, for whom only those intellectuals with the ability to be in tension with their respective society are worthy of their name. Thus any new critical theoretical interpretation must go beyond the accepted and existing forms of thinking and must bring about the contractions in present day society.

Last but not least, as argued by Daniel Bensaï (2006), we need a "Marxism for our times". Yet, if the French Trotskyist synthesized the "great critiques" of Marx limiting them to his economical, historical and scientific criticisms (3), all of which remain relevant for our day and age, this return to Marx must be also a recuperation of his dialectic. In film studies, as in other fields of inquiry like art or literary criticism, there are innumerable works following these directions, already establishing important distinctions according to these criteria. There are remarkable studies about the hegemony of Hollywood films in global markets, critical evaluations of the evolution of world cinema or interpretations applied to the various forms of exploitation in movies.

But in order to make critique (as in German Kritik) different from criticism, it would not suffice to show the negative elements in a cultural object or to dismantle the contradictions within a certain content. The identifying of the practical, social and political effects is also relatively relevant. If we put into action almost all the insights put forward by Marx himself, we are not basing our method in his practice of criticizing. Neither are we inside of what the author of Das Kapital identified as his own method. The famous apothegm used by the father of materialist dialectic that is the "ruthless criticism of all that exists", used in his September 1843 letter to Ruge, 
must be further analyzed. We return to the basis of this fearless form criticizing, one which is never backing away from the consequences its own negations.

\section{The Bad, the Ruthless and the Negative dialectics}

Noël Carroll, in his post-theory debate intervention, suggested that cinema studies must become more "dialectical", proposing a new frameworks based on a pragmatic dialectical "model" (58). Since the dialectical method is an extremely complex issue, several observations have to be made about "the good, the bad and the evil" of dialectics. Carroll's presupposition is that a form of "dialectical criticism" is traceable back to Plato's philosophical practice (56), which could make film theory more "dialectical". While agreeing that the dialectical method could provide excellent foundations for cinema studies, the problem comes from the definitions we use. When purposefully overlapping criticism with dialectics, the entire purpose of the method is emptied of relevance. Just as simplicity is never the mother of knowledge, neither can the criticism of previous theories provide a deeper understanding about cultural or social meanings. An apparently functional dialectical model, although designed to provide pragmatic results, is in fact revisionism and it can be counterproductive. By reconsidering the value of previous theories, by overviewing their historical basis and by having those theories "compete" with others, we can achieve no new understandings. The "dialectical" dismantling of the validity of Roland Barthes' observations about mythologies cannot go beyond criticizing this author. More so, when cognitivism is presented as a "dialectical" alternative when competing with psychoanalytic theories, this breaks even the rules of the Greek dialektike, which might have been the art of debating your opponents words and ideas, but it was never a partisan instrument.

In my opinion, this is a bad form of dialectics. By simply identifying oppositions and formulating observations against our "adversaries" we can never achieve more than a confrontation with a pre-established result - we are right and the others are wrong. The polemical dimension is only the beginning of the dialectical process and, more importantly, the practical use of the model is hardly functioning when the opponents have no contribution in the debate. Dialectics as an ancient intellectual procedure, with its obvious roots in Plato's dialogues, was practiced as a dialogue based procedure. However, its dialogical nature makes it practicable only in a dialectical settings, where the questions are the engine of getting the right answers (Fink 5).

There is another function of the method which allowed many authors to ascertain its development in a long line of thought, connecting ancient Greek philosophy with critical theory today. We can identify it in the Socratic practice of dialektike, not just as an antagonistic dialogue based procedure, but also as a mode of reasoning, using the "method of division" (diairesis) in order to achieve a moment when no more distinctions were possible in the debate, thus the truth was identified. Elementary as this seems, it contains the basic technique of any critical thinking, that of purging 
the false beliefs and expunging them from the mind of the interlocutor. From the maieutic practiced by Socrates, through Fichte's triad, to Hegel and Marx, then to Adorno's negative dialectics the method itself had several functions, innumerable definitions, but only one purpose.

This is why, following Fredric Jameson, we need to distinguish between two separate manifestations, to separate the dialectical thinking and "the dialectic" as a specific method (4). It is not simply about contrasting philosophies or putting ideas in antagonistic dissension. The opposition of concepts or the dynamic contradiction between theories does not provide the much needed discovery of truth. Such approaches have to be disqualified as simplistic and sophistic intellectual games. Albeit atrocious for post-theorists, a careful reading of Adorno's 1958 lectures, published later as a single volume (2017) could have spared us of this discussion. Reducing dialectical operations to the logical instrument itself or transforming the contradictions in practical results are vulgarizations of the method or "egregious intellectualizations". Unfortunately we can find this most harmful confusion in many works, and Karl Popper's critique of Hegel (1968), which also expands to Marx, illustrates how common is the misunderstanding of what the dialectic method does. By identifying the binary oppositions between a thesis and and antithesis, then providing a synthesis would lead to gratuitous effects, if by this we achieve only a quick conclusion of the dialectical conflict. The method remains empty if it is "dialectical" in and of itself. Without providing deeper understandings of the roots of the contradictions it is only a vulgarization and caricaturization of reason.

Another important aspect, also pointed out by Jameson (10), is that dialectics cannot be considered as a "unified philosophical system". The Hegelian idealist dialectical thinking is clearly different from the Marxist "diamat" (or dialectical materialism), and also Adorno's revised version of utter negative functions. Many post-Marxist thinkers have further elaborated on the method itself, and we could speak volumes in order to describe all the contemporary transformations, from the Lacanian psychoanalytical approach to Žižek's revisions of Lacan.

The modern dialectic cannot be understood without returning to Hegel, since many of the qualities of the method and the formulas we use today can be attributed to the author of the Science of Logic. In his intellectual debate with Kant, Hegel was looking for a scientific method of thinking and he discovered "the magic" of the dialectic approach. After overviewing the evolution of dialectics from Plato to Fichte, the German philosopher connected this technique of inquiry with the fundamental mechanisms of reasoning and reached to the conclusion that its principles were an expression of Nature itself. This conceptualization remains extremely accurate today, and the suggestion that there is a mechanism governing nature, also valid in human history is fundamental. If everything "in heaven and on earth" contains the principle of dialectic and is a result of dialectic tensions (61), then the purpose of dialectics as "the grasping of opposites in their unity" and the "positive in the negative" (35) is more 
than a debate about contradictions. In fact for Hegel the "sophistry" practices were forms of empty dialectical mechanism (80) and he rejected them, substituting such contradictory arguments with the principle of sublation (aufheben) or a "determined negation". Finding "the positive in the negative" is not most difficult dimensions of the dialectic, since "the power of the negative" only brings out the negation from the core of the arguments. The method itself supposes to take the negative to a higher understanding.

Although often charged for the elaboration of the dialectic triad (thesis - antithesis - synthesis), these claims are unfounded. Hegel never proposed the reduction of every argument to a basic dialectic instrument. In the Science of Logic he often denounced the subjective use of dialectical dialogue, as practiced by the sophists in Ancient times, which he identified as "common dialectic", a little more than "ordinary" thinking. The "triad" was implicitly rejected by Hegel as he affirmed that the dialectical approach was never only part of a logical or a scientific discourse, in its Kantian form, nor should it be used as a formulaic refutation. Hegel's criticism was inherently a critique of a "critique" (in this case several Kantian critiques), where he denounced the "infinite nothingness" achieved by making the dialectical model a negative attitude towards every opposing idea. To fully apprehend dialectical thinking is more than using it as a criticizing instrument, one that constantly negates and dismantles the existing ideas. The very principles of dialectics are never is reductionist, nor infinitely theoretical. Dialectical thinking offers access to the illusion of all essences of things, ideas and representations.

This development of dialectics goes through Marx, who was also searching for a philosophical instrument which could provide access into the essence of history. His pursuit of a "true dialectics" led him to a radical revision of the Hegelian technique. Marx considered that the Hegelian dialectic was "standing on its head", thus he defined his own method as a "direct opposite" of the Hegelian "idealist" mode of practicing the dialectical method. This is why the Marxist materialist principle is often labeled as a materialist dialectics, later simplified as "diamat". However, the profound change operated by Marx was not simply turning dialectic back on its feet, or the abandonment of the "mystical" dimensions and its idealistic purposes. As the philosopher turned revolutionary acknowledged in the"Afterword" of the second German edition of Capital(1873), he refused to treat Hegel as a "dead dog" and argued for a "dialectic" which was only "critical and revolutionary", a way of thinking that must be an "abomination to bourgeoisdom".

Even if for his later Marxist-Leninist followers, this type of dialectics became a doctrine, the creator of this practice did not intend it only as a form of radical polemical discourse. We must understand that the first action of the new dialectical approach comes from the criticism of the idealist critique and followed by the need to actualize the dialectical form of thinking. Yet the purpose of this method is not to enjoy a particular line of thoughts. It is refusing speculative criticism and 
replacing it with an interpretation of practical problems. It is a common knowledge that Marx, striving to provide the Hegelian dialectics with a historical base and a scientific foundation, that he believed could generate irrefutable results, considered historical and social materials in their "momentary existence" as more important than any "transcendental" manifestations. In the sense, the Marxist dialectic can defined as materialist, since its inventor was certain that the "material" components of the world were made visible in the "Ideas", and not the other way around. This is why the practice of dialectical materialism, as refined in the Capital, focuses on economic contradictions - its creation must be understood in the practical context and the historical conditions in which was developed. However, the mechanisms described by Marx - based on the observation that all manifestations in history and society contain contradictions and are profoundly antagonistic - leads to some inevitable conclusions. It is not simply observing the transformations of an initial manifestation (the thesis about capitalism) into its opposite (an antithesis about class struggle), then finally uniting these tensions into a negation of the negation (that is a synthesis which could be communism). Reduced to its negative dimensions, the Marxist dialectics gets some important answers, but they are not sufficient in and of themselves. Engels explained how the concept works, returning to the Hegelian sublation, when attempting to describe how the apparently complex negation of the negation operates in the works of his friend and fellow thinker. By negating the central thesis of capitalism and by providing obvious results from this negation, the Marxist praxis is also a victim of its own method.

While the classical Marxist dialectic was an instrument specially designed to account for the pragmatic dissensions within capitalism, to analyze the dialectical tensions of the capitalist forms of production, we need to grasp another important dimension, if we are to take hold on the thought process of Marx. Some authors (Ollman 2003) attempted to take the method apart and suggested that the dialectic "explains nothing, proves nothing, predicts nothing" (12), describing it as only a process of "abstraction", which is moving from the "real concrete" of existing situations, to the dismantling of these realities, then to the "thought concrete" of possible solutions (60). While the structure of the Marxist thinking working close along these lines, the movement from identifying the contradictions of capitalism to reaching the hidden dimensions of such antagonisms is extremely complex and nuanced. An astute critic of capitalism, Marx was not simply denouncing the contradictions of the economic system in order to obtain "thought provocative" effects. He was exercising a type of criticism he identified as "ruthless" (Marx 1843). Practicing a brutal analysis "of all that exists" he dos not back down even when the conflictual consequences or the antagonistic results are troublesome. This is why the Marxist dialectic has to be described as brutal, with many of his enemies denouncing his acceptance of violence or of inhuman solutions as an abandonment of humanism, yet the purpose was to follow the dialectical reasoning to the end of its course. 
I will return to the Marxist method, yet for the sake of this current argument I will briefly simplify the inner devices of the "brutal dialectic", since its mechanics appear very simple, yet its results are extremely difficult to ascertain. Marx practiced his savage dialectical thinking, as clearly exposed in "The German Ideology", with utter lucidity. The traces of this savagery are visible everywhere in the Capital. They are so trenchant that they it is impossible to ignore them even today. The connections Marx established by analyzing hundreds of years of capitalist hegemony cannot be dissolved in sophistries and are not diluted by thoughtless banalities. The contradictions of the capital have not disappeared, neither the intrinsic antagonisms of a society based on capitalist exploitation. Das Kapital is still actual today, as indicated by the most recent banking crisis and the crash of 2008. Exposing the fake thesis of the capitalist system, that private property generates prosperity, denouncing the contradictions lying inside the ideology of this system, which are visible in the antagonisms that are embedded its foundations, Marx observed that the economical base of capitalism and the superstructure of the society were in a radical contradiction. Yet to claim that he was an "utopian", dreaming about communism, is a vulgarization of his thinking. He clearly understood that, just like the thesis and the antithesis are fused together, exploitation and private property are joined together by the capital. To reduce the Marxist thinking to class conflict, which was at the foundation of its political answer, means to disregard his understanding about the unstable nature of reality. As compellingly argued by many critical inquiries today, the issues of gender inequality, sexual marginalization or the vestigial problems of colonialism and imperialism continue to disclose the alienating powers of capitalism. And, as Adorno (2017) pointed out in his introductory courses about dialectics, the dialectical method as practiced by Marx was always negatively mirroring the ideals of a society which was hiding its real manifestations. At the end of the day, the dialectical critique of capitalism is a critique of the false promises of the capital itself. Last, but not least, Marx himself stated that communism was not an ideal, nor a promise of future "state of affairs" - it was a "real movement" negating capitalism.

Many have tried to cope with this legacy and often reduced this type of dialectical inquiry to a couple of "laws", the most famous being those coined by his closest collaborator, Friedrich Engels, then recuperated by Lenin: the transformation of quantity into quality, the interpenetration of opposites; and the negation of the negation. Engels (1878) attempted to further clarify the method used by his friend and collaborator. In his dismissal of Dühring's criticisms, he ironically mocked the simplistic use this thinking instrument as merely a conversational practice. Obviously, in the most profound Marxist sense the dialectic is never just an intellectual tool, a device designed to prove or disprove what somebody else argued. By calling Dühring a "crass metaphysician", Engels wanted to point out the simple yet coherent use of sublation, manifested as the negation of a negation. Illustrated with numerous examples, from the transformation of the butterfly, to the geological transformations, 
then to mathematical changes, Engels is using an example which could be understood even by a child. Anti-Dühring provides one of the clearest definitions of dialectics, described as a universal law that govern nature, society and human thinking. Just as the grain of barley is transformed into thousands of other grains, so does the dialectical materialism extracts meanings from the death the historical processes. As underlined by the co-founder of communist thinking, the "dialectical laws" can take us to the understanding of history, economics and any other social manifestation.

Lenin came along and proposed his own revision of the method, claiming in his notes that, for over a century, "Marxists did not understand Marx" (Lenin 1978 180). Unfortunately, by reducing everything to the laws of dialectical thinking, the Marxist-Leninist dialectic ended up as just another simplification of Marx, causing innumerable misconceptions and even tragedies. The founder of the Soviet state used materialism against empiro-criticism (1909), and combated with the "reactionaries" who "muddled" the thinking of the forefather of communism, specially against the Russian "Machism". Lenin's views were often blatantly antagonistic and his answers founded on a schematic revisionism of materialist, focusing on the "essence of the matter" manifested in the active forces of history.

Perhaps the most egregious emendation of Marx's method, with awful consequences, was Stalin's adjustment of dialectical materialism. Removing the very cornerstone of this wonderful intellectual tool, the negation of negation, the ruthless ruler of the Soviet Union reduced Marxism even. Although Althusser happily agreed with the removal of the negation of negation, the result was one of the most primitive understandings of the dialectic. Its expression can be found in Stalin's work published in 1938, called "Dialectical and Historical Materialism". In this "for dummies" version of Marxist thinking, Stalin regurgitates the idea that dialectics is supposed to be opposing metaphysics, and then moves to the Darwinist theory of evolution as a proof that materialist dialectical transformations were at work in nature, thus applicable in society (Stalin 1943). Seen as a "disclosure of contractions", or, as it was underlined in Lenin's "conspectus" on Hegel and this topic, later reunited in a volume called Summary of Dialectics, dialectical criticism is based on identifying those instances in which contractions are manifested as unified meanings, then finding how these laws of nature and society can be applied.

Finally we need to briefly discuss a third major moment in the development of the dialectical method, which is the negative dialectic in the formula proposed by Adorno. This early recruit of the Frankfurt Institute of Social Research developed his own immanent critique based on the dialectical observation that contradictions are at the core of all social manifestations. As Adorno points it, society itself cannot function without antagonistic tensions so the only possible intellectual approach is the critical positioning, where negation is contained by its own dismissal. The result of this negative understanding of the role of dialectics is fundamentally an endless interpretation, which takes the dialectician to the outer limits of the negation of 
negation, always facing the fact that an impossible synthesis is resulting from the ceaseless destruction of its results. Knowledge is never possible because the negation does not imply the discovery of an affirmative result, but the excess of interpretations. In fact only by exaggerating the results of each negation we can discover the elusive nature of meanings.

As explained by Suan Buck-Morss (65-66), although the "negative dialectics" and this "logic of disintegration" practiced by Adorno were often identified with the overall philosophy of the Critical Theory, there never existed a single method common to all the members of the Frankfurt Institute, nor, for that matter for their later followers. So, if there are multiple dialectical points of view, which of these we can identify a the most efficient instrument, which would provide the best results?

\section{Marx and the camera obscura method}

I would suggest, once more, the need for a return to Marx. Since the author of Das Kapital often referred to his intentions of writing a great book on Dialectics, but was never able to do so, we have to trust Engels, who considered it was his duty to explain the method. However, this did not prevent the accusations that Marx used dialectics as a "crutch", a tool to support his critical interpretations, without any basis in scientific research. Even for the Marxists who wanted to find the "real essence" of Marxism, his dialectic seemed difficult to grasp, and it was oftentimes compared to a "hocus pocus art" (Ollman 59).

Unlike some disparaging anti-Marxists who, like Thompson (153), claim that they are incapable of finding any method in Marx or identify what his dialectical principles are, any reader of the Capital could extract the beauty of this thinking in action. Nevertheless, since Marx himself acknowledged that the dialectical method can be applied wrongly, and that the fallibility of this wondrous mechanism comes from its mishandling, I feel compelled to trace my own methodological foundations in a line of thought deserving a brief overview. Also, because I consider dialectics to be the most important instrument we have in interpreting movies, and in order to dismiss its practice as a negative commentary about other film theories, I want to return to the core of the method employed by Marx. As pointed out before, it is not only a theoretical form of criticizing, it must be practiced as a fully fledged critical method. Clearly, when engaging in numerous debates with his contemporary philosophers and opposing thinkers, Marx always exercised a virulent form of critique. But the power of critical evaluation is provided by the refusal of speculative thinking, and not just seeking contradictions for the sake of denouncing the fallacies of the opponents. So what is the dialectical method about, what gives its scientific foundations, beyond that practiced by Marx in his economic texts.

The most explicit clarifications come from The German Ideology (1846), where Marx uses the camera obscura metaphor to characterize how ideology affects our thinking by falsifying consciousness. In the first part of this manuscript published 
long after the death of Marx and Engels, we have the definition of ideology - it is a set of representations which makes "men and their circumstances appear upsidedown, as in a camera obscura ...". More important for our present discussion is the process that makes allows the production of ideas to be projected in our minds. If the fake ideas generated by ideology are "fantoms", formed in the human brain by a larger mechanism of mystification, how can we distinguish them from real ideas? Capitalism is concealing its contradictions and antagonism in various forms, and, just like the inversion of the retina transforms the physical manifestations, so does fake consciousness project human life upside down.

This is best illustrated by cinematic representations, where we can discover innumerable hidden aspects of the social conditions which allow the ideology to be formed in our minds the other way around. As noted by Marx, while consciousness should be naturally created by human life, ideology induces fake beliefs, false ideas are turning upside-down the reality. Practiced as a form of cultural interpretation, a dialectical approach to cinema should identify the expressions of fake consciousness, not only to analyze the material or formal instruments which allow this consciousness to appear. Once identified, the dialectician must formulate these contradictions and basically show them in their real shape.

Most of the key Marxist ideas are the result of this process of dialectical reversing. One quick example could show how important this type of explanation can be, and how the negation of negation formula can give instant results. In a famous passage in the volume one of the Capital, Marx discusses the pathway from private property, to capitalist property, through the historical process accumulation. The main illusion projected by capitalism is that labor represents a form of ennobling human beings. To this thesis the obvious antithesis is that the result of work comes in a form of theft, that is the owners are stealing the results of the labor from those who actually produce it. This contradictory thesis exposes alienation as the main mechanism of estrangement. The reality presented as true and desirable (labor) is in fact a disguised negation of its own falsity (exploitation), and exposing its falsifying effects is the criticism of capitalism.

There are many studies applying the Marxist principles in cinema. One of the best examples are provided by the seminal work of Stephen Heath (1981), illustrating how cinema conceals the contradictions of capitalism within its illusory projections. In movies these contradictions are deeply sutured in three distinct levels: narratives, or cinematic texts, mechanics or camera works and industry (7). In fact this is why the relevance of Marxist theory in film studies can never be depleted. As indicated by many recent studies, "taking Marx to the movies" produces valuable insights, mostly at the relative plane of applying some of the concepts from the Capital into various productions. Studies on class struggle and exploitation in cinema, as is the case with the volume coordinated Leigh and Durand (2013) or the edited work of Ewa Mazierska and Lars Kristensen (2014), showcase how the Marxist approach to 
cinema produces important research. These books are extremely relevant not only due to the economical and political actuality of their criticism, but because they expand the consequences of the method of inquiry developed before the creation of contemporary movie industry.

Not all film studies are examples for how we can expose the dialectical antagonisms of capitalism in cinema representations. There are interpretations of films which bring other theories into the dialectical mix. Slavoj Žižek is perhaps one of the most prolific and outspoken critics, denouncing not only the economic dimensions of the cinematic deception, but also its perverse inner mechanics. Žižek adds here his own Lacanian perspective, by integrating the notion of perversity into the debate about ideology (1989). His thesis is once more dialectical, because he claims that always the first idea, the wrong impression made by the object of our desire, in this case a movie, is wrong. When seeing the effects of the fake reality on our minds, a second movement is to observe its paradoxical nature, and then reaction should be laughter. Faced with deception in movies we need to overcome the enjoyment (as jouissance) offered by the visual display of these pleasurable events, even if the perverse consequence would be the impossible enjoyment. Many of these views were presented by Žižek in the popular documentary, The Pervert's Guide to Cinema (2006). There he proves that there is a deeply practical dimension to film theory and the accessible nature of the explanations are important in the overall apprehension of difficult concepts. For example Žižek discusses the scene in The Birds when Melanie arrives at Bodega Bay. As she is hit on her forehead by a seagull, the analysis of the scene from a formal point of view would provide maybe general observation about framing or composition. However, this apparent insignificance must be negated, as the representations in the visual field are never explainable only at the superficial value of the image itself. Neither can we remain at the level of the narrative structure. These are only the first appearances of the deception. The second movement would be the recourse to the classical Freudian revelation, the discovery of the Oedipal relationship, the sexual tension of the presence of the maternal Super-Ego and so on. The clash between Reality and Fantasy is even more important, as it exposes the underlying role of false consciousness. Because the mirror of the cinematic screen always deludes us, we need to follow Marx's intuition and reverse its effects.

In my own opinion, the Marxist film theory is too often providing formalized interpretations of movies, focusing more on applying old terms and concepts into recent contexts. Of course, as noted by Kevin Durand (4-5), cinema illustrates the major antagonisms of capitalism, like class conflict, oppression and even imperialism. Investigating how cinematic representations are allegories of the oppressed and the working class (from the replicants in Blade Runner or the subjection of humans in The Matrix) can be intellectually rewarding. Read into each film the presence of the proletariat or the alienation of the labor from its class consciousness keeps critical theory a the stage of an unoriginal application of the concepts advanced by Marx, 
Engels or even Lenin. Many movies are natural expression of socialist values, which was noted by the censors of brutal capitalism, who banned Chaplin's works depicting the misadventures of the Tramp, perceived as "communist". The fact that the actordirector was banned from re-entering the United States during the "red scare" and the terror of McCarthyism is indicative for how important movies are in contemporary ideological wars.

By practicing film theory with a critical attitude towards society, the cinematic remains a secondary phenomenon, as pointed out by the detractors of Theory. Nevertheless, describing the cinematic components (improperly identified as formal) of a movie is not unimportant to the critique of cultural, political and social dimensions of movies. While no movie is empty of ideological meanings, neither can the contents be converted into significations without the use of the codes carrying political signifiers. Thus any criticism of content, any analysis of the effects or any critique of production apparatuses must be supported by methodic comprehensions on the material of the movies. Interpretations do not have to be practiced as diamat, the materialist dialectic in which ideas are antagonistically resulting for matter, but also by connecting the social and the cinematic.

Definitely the most relevant illustration for this process remains Kracauer's insightful interpretation of German Expressionism as an anticipation of the Nazi regime (1947). Understanding that movies are not simply records of reality, or fictional projections of impossible worlds onto a screen, makes film theory and film studies scientific and relevant beyond the immediate experience of the moviegoer watching cinematic illusions. Kracauer defined his interpretative instruments as empirical-sociological procedures, and in the classical work on the theory of film (1960) he also suggested that it must look for "material evidence" whichh could provide an comprehension of the things that we normally do not want to see or of those we apprehend only superficially (306-307). As the film theorist observed, the most dangerous contraption of film making is not the ability to project fantasies which entertain us, but to pretend it has no connection with reality. Following the central presupposition, shared by almost all the members of the Frankfurt School, Kracauer pointed out the fact that the social reality in movies is based on a materiality of though, as all films are "materially minded" (309). We need to escape from the "film reality", to go beyond the magic of cinematic images, to dispel the hypnotic fascination exercised by the dark room of the movie theater, if we want to escape the straightjacket of ideology.

Another model for how "dialectics" can be practiced, although not dealing with movies, is Adorno and Horkheimer's study published in 1940. The Dialectic of Enlightenment remains one of the most important studies, providing an overview for how false ideas, in this case our misconceptions about "Enlightenment", are exposed to the refreshing air of dialectical thinking. Contradicting the thesis about the effects of the "Age of Reason", a time in the history of mankind in which 
positive transformations have liberated humanity. The two most important critics of the Frankfurt School, identified a deep contradiction within the manifestations of Enlightenment, expressed its dark compulsions. By reframing the benefits of reason through the negation of negation, they reached the logical conclusions that one of the horrible consequence of this "Reason" was its own irrationality, manifested not only in the Nazi atrocities, but in the modern massification of cultural consumption. This highly influential work shows how the dialectical method can always generate insightful results. Adorno and Horkheimer exposed how Western rationality serves as an opposite instrument of own promise - "Enlightenment" was turned into its own negation of negation, a form of oppression made possible by the cultural industries that were supposed to bring intellectual improvement. Of course, contemporary cinema plays an important role in the debasement of reason induced by the entertainment industry.

\section{The Science of Mickey Marx:}

\section{Reflections from the double dark mirror of fluid dialectics}

There are many dialectical approaches to cinema and film theory, as suggested inconsistently by Carroll, can indeed become "truly dialectical". Yet harnessing the power of dialectics is never simple, and although the technique itself remains a "divine process", in Marx's own words, its application remains often a mechanical extraction of Marxist topics from the movies. Rarely the dialectical method is understood and properly practiced as there are various competiting "dialectics" at work.

Many recent examples illustrate how the apparent diversity of dialectical approaches can be confusing. Some, like Zachariah Rush (2016) proposed a dialectical analysis of movies from the simplistic understanding of the dialectic as "the unity of opposites in conflict". Thus everything can become "dialectically" relevant, even the "existential dialectics" of movie characters. Fabio Vighi suggested a return to a type of dialectical thinking founded on Adorno's conceptualization of the negative dialectics (2012). So Vighi applies his own negative approach to American noir films, speculating on the paradoxical nature of these productions, on one hand resulting from the industrial drive of Hollywood, and on the other influenced by an artistic, European aesthetics (19). This is another mechanical vision about the dialectic method. Although this author claims the has identified the major "weakness" of the Critical Theory (and of Western Marxism) from the "displacement" of Marx's theory from the political economy, where it was justified, to a more general form of criticism of society, and implicitly of cinema (5), his answers to this problem have no major consequences. When it comes to analyzing movie productions, this dialectical analysis of the noir simply points out the inner tensions of the movies and claims they are reunited in a "symbiotic" manifestation, a new cinematic genre.

There are many other gross simplifications of the "Marxist analysis", as are Arthur Asa Berger's "techniques" (2018), mostly borrowing from Eric Fromm's re- 
interpretations, taking further the presupposition that it must be a "materialist" approach, which consequently must focus on social, political and economical factors. A Marxist cultural analysis would necessarily bring about discussing the modes of production, overviewing the concept of alienation or evaluating the relationship between the base and superstructure. These applications of the Marxist method must denounced as forms of vulgarized Marxism, and I am convinced that the author of Das Kapital would have rejected them himself, probably uttering his famous and ultimate negation: "I am not a Marxist".

I must say the same about my own dialectical approach to film analysis, I am using Marx without being a Marxist, which makes me a "Mickey Marxist". Sketching another framework, an interpretive mechanism already practiced in my previous explanations about James Cameron' Avatar (2009), or the Mad Max franchise (Pop 2009; Pop 2015) is necessary. In fact it is a variation of the negation of negation, characterized by the principle of the double dark negation. My contribution to the dialectic conceptual effort was to mix the dialectical sequence with the idea of the double mirror, borrowed from the myth interpretation proposed by Northrop Frye. In his interpretation of Biblical myths, Frye identified the the double mirror as a tool often activated in ancient storytelling, observing that they were displaying a form of reflection on themselves, a dual "U turn" movement (91-98). Since myths are the most complex forms of ideology-making, when movies generate significations which project negative reflections of their own negations, these signifiers can become indicative for deeper meanings. In Avatar (2009), for example, the legends of the past, elaborated by American native Indians, were folded into the fantastical projections about the future, and in fact hiding the terrible present references. These operations of the double mirroring are made apparent by many other " $U$ "-turns practiced by James Cameron's myth-making. The term double dark mirror brings the negation of negation to the reflective surface of two canvases that both hide the true meanings. It also makes an explicit connection with the "camera obscura effect" of ideology, since the double dark mirror reverses the process of generating fake meanings, only projecting them onto screens that negate each other's reflections. In its final projection, the double dark mirror represents the most powerful aspect of the second negative reflection of the dialectics. This apparently paradoxical process can be illustrated by the story in Avatar, which at the first impression denounces the Western exploitation of nature. Nevertheless, this image reflected in the double dark mirror becomes the reversion of its own incongruous significations, because the ultimate result of the movie is not a real account of the tragedies suffered by ancient populations, but a fictional world which appears a a masquerade, an utter negations of their own negation.

While I was sometimes referring self-ironically to this approach as the "dialectics of Mad Ma(r)x", or "the science of Mickey Marx", nevertheless dialectics remains a highly effective method, in fact one of the fundamental modes of decoding cultural objects and many other complex products of contemporary imagination. Applied to 
various cinematic examples, from the Star Wars series to the zombie genre, the double dark negation provides responses for several other incomprehensible expressions in movies. While attempting to develop my personal instrument of decoding the logic of cultural incongruences, initially my main method of interpretation was based on the double negation technique practiced in its Lacanian version, in fact a form of "suspicious dialectics" (Lacan 2001, 85). This particular approach was then nuanced by the revised form of dialectics proposed by Slavoj Žižek (2009b), which seemed to me perfectly adapt for practicing the classical "negation of negation" only in a reconfigured way. Žižek's revisal was coping with the difficult issues of emptied signs and is useful because it added to the traditional critique the dark dimension of contemporary representations. It was also relevant as it overcame the limits of the Marxist explanations about the inner tensions of capitalism, where the first negation always able to provide explanations (Engels 1878). The redefining of the second negation was more important, as it repeated the failures of the initial contradiction, thus exposing the confusions of significations (Žižek 1999b 74). While the negation of negation remains a universal law of nature, history and, more importantly culture, it must be seen as more than a form of criticizing economic relations. I am using it to gain access into the very essences of meanings, not simply into the modes of production.

When evaluating a particular movie, the practice of the first negation allows us to look beyond the immediate representations and technical characteristics. This immediate and "objective negation", if not followed by a second negation, cannot reach a third level, the one that brings us to the most valuable results. When applied on recent films, it offers some of the most revelatory responses. Instead of the so-called Hegelian synthesis, the outcome of the dialectic of the double dark mirror indicates the rifts in meaning-making. A close appraisal of cinematic works shows how they are the result of repeated negations, finally generating an absolute void of significations. Thus, instead of recreating a coherent understanding, as explicitly manifested in the retroactive forms of negation, they become illustrative for the illogical dimensions of contemporary films. Just as the French psychoanalyst observed, the specular image is basically "an error", and the Lacanian dialectics pointed out the importance of the moment when the child mistakenly believes that his image is accessible in the external representation. Like that child, we are trapped in the dialectics of desire, in the fascination for the Other seen on screen, unable to distinguish between Imagination and Reality.

Of course, there are relevant economic issues in the way that cinema functions which disclose the nature of capitalism. There are also some important elements made explicit by the double dark mirror. While Cameron's movie feigns the denouncing of the defects of capitalism, as it appears in the first mirror, the director himself is one of the beneficiaries of the capitalist accumulation. Apparently taking the side of the primitive $\mathrm{Na}^{\prime}$ vi population, he is in fact part of the global domination of Hollywood produced blockbusters and the hegemony of US distribution companies. 
According to the 2016 statistics provided by MPAA, the global market for movies was estimated at about $\$ 38.6$ billion, with 71 percent of the total sales international. So, even if the top grosses are in China, Japan, India, these movies are dominated by Caucasian characters, heroes and actions taking place in Western environments and mostly spoken in English. In 2012 the movies produced in the United States or financed by US based companies represented $90 \%$ of the films with the highest global attendance and in 2013 all the top 20 movies released that year were US made. As Douglas Kellner observed (212), this basic connection between movies and capitalist entertainment created a global industry is promoting American myth, dreams and, more importantly, ideology. So, by looking at box-office revenues, we can observe how the top selling movies worldwide are Avatar (2009), Titanic (1997) and now Star Wars: The Force Awakens (2015), all exemplifying the inner contractions of contemporary capitalism, but also of the control of human conscience. Once more, the argument provided by Marx in The German Ideology remains intact. Any critique of cinema must look at the spiritual hegemony exercised on the economic base, where the spectators consume not only beautiful images, but also fake ideas about society.

Just as the religion was "the opium of the people" (Marx and Engels 1957 39), cinema today represents the new religion, the new drug of massified society, inducing a phantasmagoric vision about the reality. Even without the help of the double dark mirror we can see these inner contractions, but we lack the necessary instrument to move further. Again, while underlining that the double negation is only a revision of the mind-boggling instrument which is the negation of negation, it also exposes the limitations of the negation of negation as we have inherited today. Incorporated into the Leninist methodology of dialectical interpretation as a "teaching" based on the principle that opposites are identical and they become identical (Lenin 109), the dialectic "law" was pejoratively practiced as a good for all explanatory instrument, foretelling the evolution of society. Since Lenin believed that all things moved from one level to another, with the "old" qualities replaced by the "new", he used the negation of negation as a justification for the replacement of capitalism with communism. In fact, as observed by a subtle anti-Stalinist like C. L. R. James, the Soviet Union was only another stage of the decay of capitalism, a form of state-capitalism (132), in fact a negation of its own negation.

With dialectics remaining an universal law of nature, history and, more importantly, ideology, the double dark negation technically allows us to decode such situations which have an enormously confusing component. The "classical" negation leads to the basic and initial forms of contradiction, and exposes the immediate falsity. When analyzing the characteristics of a cultural object, a simple first negation allows us to see beyond the immediate significations. Then the objective negation can bring us to a secondary level, where the artificial dimensions of these negated significations become explicit. Yet in circumstance in which repeated negations are put into action, the double dark negation is not only a succession of negations, but 
a return of the second negation onto its own antagonistic conclusions, then revered in the first negation. This U-turn of negations are the basis of my dialectical method.

My particular approach to this method of interpretation can also be described as a return to another Hegelian intuition, which describes the role of the double negation in the formation of the self (Hegel 1975 907). The theoretical and practical basis of this technique comes from another Lacanian use of the double negation, also nuanced by Žižek (1999 74). The double negation, practiced as an instrument which opens the hiatus between the two negative manifestations of the Imaginary and the Symbolic, expressed as the Real, is a purposeful use of negations we can "extract" meanings from otherwise impenetrable or incomprehensible contents. In fact is the same as the ancient practice of "midwifery" of ideas. It follows the basics of the dialectical method because, as explained by Engels (1878), this provides the necessary tools for explaining the "mysteries" specific to any form idealism. When it comes to cinematic projections it makes possible the decoding of cultural and political manifestations otherwise disguised as "innocent".

However, instead of the "cruel" and "ruthless" mechanism of Marxist dialectical discourse, I propose a fluid dialectics. Based on one of the most recent scientific discoveries, it completes the classical example and gives more explanations for the apparent paradoxical nature of the negative dialectical reasoning. The metaphor of the grain, expressed by Engels and then re-interpreted and re-used until its meanings are now totally negated, can be substituted with a new connection in the natural sciences. When looking for a "correct dialectical method" inspired by nature, the return to the classical descriptions of the dialectical process are important, but not enough. If the grain could have been the expression of the coexistence of two contradictory states, manifested as identical, with the two opposing states of the grain simultaneously present - the dying seed already containing the future plant, while during this transformation they negate each other - our knowledge of water is today even more powerful.

Boston University researchers Peter Poole and Gene Stanley, discovered and proved in 1992 that water splits into two different liquids when subjected to freezing temperatures. This strange substance, which can manifest in three different states (gaseous, liquid and solid), is also metamorphosing simultaneously into its own double. Water is not only a complex form of matter, indicating that the material dimensions of reality have multiple behaviors, there is another amazing ability of water. At the atomic level a drop of water can display both high density and, in the same time, low density. Interpreted in the best tradition of materialist dialectics this is not only a scientific puzzle, it also provides an opportunity for the reevaluation of how our method of inquiry can work. When water reaches a critical point in begins conveying its hidden nature, and so does any cultural object when subjected to the pressure of the critical discourse. This dialectical pressure does not have to be at the large social scale, it can be applied at the molecular level, exercised in the smallest and apparently insignificant manifestations of ideology. 
Once again, it was Lacan (1993) who already suggested that the signifiers in our subconscious are fluid (261), coalescing in our minds like the molecules in liquid crystals. Re-discussing Freud's explanations about how the structures of the Self interact, the French psychoanalyst used the example of the "Klein water bottle", which has the property of negating the initial impression that water is a homogenous material, showing the deeply unstable nature of its nature. The same is valid for significations, just as the water seems to be freely circulating, so the contradictions held together by the ideological illusions maintain their apparent cohesion even when negated. Expanding these ideas, I would suggest replacing the allegory of the grain with an up-to-date scientific correlation. The double dark mirror exposes those contradictions which are contained in apparently innocuous banalities. Like water hiding its capacities, the negation of negation cannot work when subjected to the mirroring in the dark reflections of the empty meanings. And, as water contains not only one negation of its condition, but two, subjected to environment modifications and transformations, any common cultural object can also generate various explanations. We can the "simple" surface of the water as a transparent filter for light or as a mirror reflecting our bodies. But water has many more strange manifestations. The most thought provocative effect of the phenomenon of supercooling, in which water is brought at the freezing point, but does not become ice, exposes the possibility that some molecules can maintain multiple features, some contradictory and even antagonistic with one another.

\section{Disney and Marx}

\section{or Why Do We Need Dialectics for Understanding Mickey Mouse's underpants?}

Mickey Mouse is one of those banal cultural elements which, just like water, can contain beneath its apparent lack of interest many disguised manifestations. Under apparently inoffensive and his innocent nature, the mouse created by Disney can be subjected to the double dark mirror of dialectics. Maybe not surprisingly enough, I also consider that the best argument for showing the validity of the double negative dialectical method could be provided by an interpretation of the Mickey Mouse underwear.

My own version of the "supercool dialectical" explanations purposefully refuses to follow the path of innumerable previous studies, analyzing the role played by the Disney corporation in the global expansion of capitalism (Wasko 2013). And, although extremely relevant, neither do the connection between capitalism, imperialism and the cartoon character of Donald Duck can provide new insights, since Ariel Dorfmann and Armand Mattelart's seminal work already discovers sufficient political significations (1975). And even if Walter Benjamin described these cartoons as some of the most "unsymbolical" manifestations (20), he also saw the mouse only as a disruptive figure, constantly fighting for the "little men". 
Instead I propose a brief (no pun intended) analysis of the most famous "red undies" in the world, which could prove some of the foundational observations of the Marxist critique, but also could illustrate how the fluid dialectic works. The strange gloves Mickey wears and the heavy and uncomfortable shoes are easily explained by the classical dialectic, as expressions of a deep contradiction simultaneously representing the working class (symbolized by the wooden sabots) and the bourgeoisie (the fancy gloves, accompanied sometimes by a black top hat). What fails to discover the utter commodification of the hero, simultaneously failing to provide answers both at the first and the second dialectical negation are his shorts. The underpants of other characters, like those of Superman or even the Smurfs, are ideologically and allegorically explainable

In order to understand Mickey's red boxer we need to resort to a historical negation, a first negative mirroring. The birth of Mickey Mouse happened in the middle of a type of capitalism based on ferocity, sometimes described as "savage capitalism", where everything was up for grabs and only the strongest could survive in the fight for a market share. As detailed by Christopher Finch (1988), the first creature invented by Disney was Oswald, the "lucky rabbit". The factual thesis of the first negation is based on this material argument - Mickey Mouse is a contradiction of his own identity. When Disney was ripped off by his employer, Charles Mintz, who took over his beloved creation and also his associates he was terribly frustrated. And if, as noted by Finch who documented the features of Mickey in his earliest version, we observe that Mickey was an alter-ego of Walt (24), then Oswald proves to be another negation. Victim of the master-slave dialectical relationship, which was read and re-read from Hegel, to Marx, and to Lacan, Mickey and Disney are one and the same.

This is why we must read into the Disney created a global "Mickey minded audience", in which there is a coupling of childhood and consumption (Zornado 2001 154), another profound tension. The underpants appear to be useless, a fact observable by comparing the characteristics of Mickey with those of Donald Duck - who wears no shorts, yet always an blue overcoat. Yet, when compared to Oswald, Mickey wears similar clothes. This physical appearance of Mickey is coalescing simultaneously two contradictions - he is a grown man behaving like a child, and also a child with adult traits. This apparently non-contradictory cohesion is held together by his underpants, buttoned by two buttons without any other function than to indicate this antagonism. Both infantile and mature, Mickey generates the negation of his own negation. In the double mirror of negations he is the opposite of everything he apparently promotes.

Benjamin was right at this superficial level, the Mouse is an expression of rebellion. Disney's first successful depiction of the character, the short film Steamboat Willie, screened in 1928, presents the happy go lucky mouse in a confrontation with the mean and domineering cat named Pete, who always bosses him around. Once more, this first antagonism is culturally explicit. Mickey resembles Chaplin's "Tramp" and they both negating the reality of the American society hardly recovering from the 
economic crash by giving the little men a voice. The are proletarians who accept their condition, just like Mickey who is presented in the early movies as accepting menial jobs. Just like in Disney's later production, Fantasia (1940), he is an inferior laborer, a proletarian coerced to do things he does not like. Then, through a magical device - in Fantasia an anthropomorphized broomstick or in other cartoons by sliding into a dream-like state - he overcomes his slavish condition. By entering these Magical worlds he performs a second negation, and this is where things become problematic.

Because it is in this magical world of Disney that the double negations takes their dark U-turn. Just as the fabulous castle in the Disney World logo is a copy of the Neuschwansteinpalace built by the mad king Ludwig in the honor of Wagner, the stories of the Mouse have a negative appeal. We know today that Hitler was one of the greatest fans of Mickey Mouse, and that Goebbels himself offered the Führer dozens of animations as his Christmas gift (Urwand 12). In fact in 1938 Roy Disney, Walt s brother and partner, visited Germany and sold Snow White and the Seven Dwarfs to the Propaganda Ministry of the Third Reich, a movie which apparently Hitler loved very much. We could also discuss Disney's racial policies. His collaborator animator, Art Babbitt, affirmed that the creator of Snow White was participating at the reunions of the German American Bund, or the American Nazi Party and although the company was enrolled in the anti-Nazi propaganda during WWII, with movies like Education for Death: The Making of the Nazi (1943), these accusations were never dismissed. Last but not least, another proof that the famous mouse is only an empty carrier of significations is provided by the news story about the Palestinian TV station supported by Hamas, who used a fake Mickey Mouse character to teach children how to wage war against the enemies of Islam (Spiegel 2007).

More importantly, just as some greedy capitalist took Oswald from him, Disney felt entitled to take Snow White and most of his stories from the Grimm Brothers, who could claim no copyright, making them proprietary values. So Mickey is not only the happy worker always singing, dancing and enjoying life even if he is coerced to physical effort. As already pointed in another remarkable work published by Joseph Zornado (2017), who is also following the consequential Lacanian dialectical interpretations, after the "Great Depression" Disney became one of the most important "lubricating" instrument for the fantasies of capitalism (35). This is a "Magic Kingdom" over the clouds, as indicated by the slogan of this global company, albeit it is a fictional place where all fake forms of consciousness can take shape. Just as Oswald was alienated, his negative double, Mickey is today helping the alienation of innumerable generations. The innocent Mouse has reached the level where he operates as a sign for global exploitation and of capitalist appropriation of meanings. He is not only a negation of the entire social tensions between the exploited and the exploiters. If we go beyond this first negation, hiding the importance of class struggle, we reach the point where his underpants provide the "supercool" meanings. By wearing childish pants Mickey's sexuality is infantilized. Here is the first level 
of negation, that is the clear annulment of his genitals. The dark reflection of this negation is the global castration operated by the puerile sterilization of all Disney productions. So to say this is hidden in the second negation of the pants, as they become signifiers of the underdeveloped ego of the Disney consumers.

As argued by Bell, Haas and Sells, Disney has become an ideology (2-3), one internalized by billions of people all over the world. And, just like the hybrid rodent created by the Cambridge scientists, called "Mixy Mouse" - since he carries both black and white genes - the Disney mixtures are always hybridized. Almost always a subject of aggression and abuse, Mickey accepts the coercion of the "Other". As the Lacanian dialectical logic explains this antagonistic bond of desire between the " $\mathrm{o}$ " of the unstable Self and the capital letter "other", our identities are constructed by following the desire of others, accessible only as a form of inaccesible jouissance. The refused identity of the global Disney films consumers gets codified in the projected and desired identities of the others we see onscreen. This Fantasia is a distorted projection of masochistic desire, which, as Seán Harrington (2015) observed, accumulates into a complete perversion, simultaneously a childish enjoyment and divulging a fetishism beyond the pleasurable fantasy.

We could engage each of Disney's cinematic masterpieces both from the perspective of the classical dialectic framework and from the double dark and fluid dialectics proposed here. One final provocative discussion about how this imagination functions is provided by another example, illustrating how the double mirror of negations is operating. In the 1936 short animation, Thru The Mirror, we see the "real" Mickey sleeping. Suddenly his body double departs his body and he starts looking into the mirror on the wall, quickly discovering that there is a flexible nature of representations - no point opening a large analysis of the speaking mirror bestowing qualities on women. The material of the glass becomes pliable and allows the double of Mickey to pass through the thin layer of reality. This surrogate creature, behaving like a completely autonomous being, enter a parallel universe, which is a perfect replica of the original, only the object are anthropomorphized.

We cannot avoid noticing that these objects are extremely similar to those from the later Beauty and the Beast (1991), anticipative representations of the entire Disney universe. Here the first representational negation (Mickey not being Mickey) is followed by a second negation (the world is not what it seems), yet both contain their own negations. In the Magic Kingdom everything is upside-down, the rules of the "Real" do not apply and this is why they provide the viewers with the utmost form of amusement and pleasure. The moviegoers who are getting entrapped by the Disney magic, when the glide into the cinematic or televised fantasies, cannot escape the double dark mirror from inside. The only liberation is when we reflect each side of these negative projections with the help of the dialectical method, which helps us "unmute" Mickey's infantile voice and provides the power to discover the mysteries of his red buttoned shorts. 


\section{Works Cited}

Adorno, Theodor W. Negative Dialectics. Translated by E. B. Ashton. Routledge, 1973 (first edition 1966).

Adorno. Theodor W. An Introduction to Dialectics. Polity Press, 2017 (first German edition 2010).

Althusser, Louis. For Marx. Verso, 2005 (first French edition 1965).

Bell, Elizabeth, Lynda Haas and Laura Sells, editors. From Mouse to Mermaid: The Politics of Film, Gender, and Culture. Indiana University Press, 1995.

Bensaïd, Daniel. Marx for our Times. Translated by Gregory Elliott. Verso, 2006.

Benjamin, Walter. "On Mickey Mouse”, in A Mickey Mouse Reader. Garry Apgar ed. University Press of Mississippi, 2014.

Berger, Arthur Asa. Media Analysis Techniques. Sixth edition. Sage Publications, 2018.

Bordwell, David. Making Meaning: Inference and Rhetoric in the Interpretation of Cinema. Harvard University Press, 1989.

Bordwell, David. "Historial Poetics of Cinema", in The Cinematic Text: Methods and Approaches, Palmer, R. Barton, editor. AMS Press, 1989.

Bordwell, David, and Carroll Noël. Post-Theory: Reconstructing Film Studies. University of Wisconsin Press, 1996.

Bordwell, David. Slavoj Žižek: Say Anything. 2005. http://www.davidbordwell.net/essays/ zizek.php.

Buck-Morss, Susan. The Origin of Negative Dialectics: Theodor W. Adorno, Walter Benjamin, and the Frankfurt Institute. Paperback ed. 1, Free Press, 1979.

Carroll, Noël. Mystifying Movies: Fads E Fallacies in Contemporary Film Theory. Columbia University Press, 1988.

Dorfman, Ariel, and Armand Mattelart. How to Read Donald Duck: Imperialist Ideology in the Disney Comic. International General, 1975.

Engels, Friedrich. Herr Eugen Dühring's Revolution in Science (Anti-Dühring). Leipzig, 1878. https://www.marxists.org/archive/marx/works/download/pdf/anti_duhring.pdf.

Finch, Christopher. The Art Of Walt Disney: From Mickey Mouse to the Magic Kingdoms. Portland House, 1988.

Fink, Jakob L. The Development of Dialectic from Plato to Aristotle. Cambridge University Press, 2012.

Foucault, Michel. Qu'est-ce que la critique? suivi de La culture de soi. Vrin, 2015.

Frye, Northrop. Biblical and Classical Myths: The Mythological Framework of Western Culture. Edited by Northrop Frye, and Jay Macpherson. University of Toronto Press, 2004.

Harrington, Seán.The Disney Fetish. John Libbey Publishing, 2015.

Heath, Stephen. Questions of Cinema. Indiana University Press, 1981.

Hegel, Georg Wilhelm Friedrich. Aesthetics: Lectures on Fine Art. Translated by T. M. Knox, vol. II. Oxford University Press, 2010.

Hegel, Georg Wilhelm Friedrich. The Science of Logic. Cambridge University Press, 2010. 
Horkheimer, Max, and Theodor Wiesengrund Adorno. Dialectic of Enlightenment: Philosophical Fragments. Edited by Gunzelin Schmid Noerr. Stanford University Press, 2002.

Kellner, Douglas. "Culture Industries”, in A Companion to Film Theory. Edited by Toby Miller and Robert Stam. Blackwell, 2004.

Koselleck, Reinhart. Critique and Crisis: Enlightenment and the Pathogenesis of Modern Society (Studies in Contemporary German Social Thought). The MIT Press, 1998.

Kracauer, Siegfried. Theory of Film: The Redemption of Physical Reality. Oxford University Press, 1960.

Kracauer, Siegfried. From Caligari to Hitler: A Psychological History of the German Film. 3rd pbk print. ed. Princeton University Press, 1970, first German ed. 1947.

Lacan, Jacques. The Psychoses, The Seminar of Jacques Lacan, Book III 1955-1956. Edited by Jacques-Alain Miller, Translated by Russell Grigg. Routledge, 1993.

Lacan, Jacques. Autres écrits. Editions du Seuil, 2001.

Latour, Bruno. "Why Has Critique Run out of Steam?" Critical Inquiry 30 (Winter), 2004. http://www.bruno-latour.fr/sites/default/files/89-CRITICAL-INQUIRY-GB.pdf.

Leigh, Mary K., and Kevin K. J. Durand, editors. Marxism and the Movies: Critical Essays on Class Struggle in the Cinema. McFarland, 2013.

Lenin, Vladimir Ilich. "Philosophical Notebooks", in Collected Works, vol. 38. Moscow: Progress Publishers, 1978.

Lenin, Vladimir Ilich. Materialism and Empirio-criticism. Critical Comments on a Reactionary Philosophy. Zveno Publishers, 1909. https://www.marxists.org/archive/lenin/works/1908/ mec/index.htm.

Marx, Karl. "Afterword to the Second German Edition (1873)", Capital, vol. I, 28.

Marx, Karl. Letters from the Deutsch-Französische Jahrbücher. Marx to Ruge, 1843. https://www. marxists.org/archive/marx/works/1843/letters/43_09.htm\#criticism.

Marx, Karl, and Friedrich Engels. https://www.marxists.org/archive/marx/works/1867-c1/p3.htm The German Ideology. Progress Publishers, 1968. https://www.marxists.org/archive/marx/ works/download/Marx_The_German_Ideology.pdf.

Marx, Karl and Friedrich Engels. On religion. Foreign Languages Pub. House, 1957.

Mazierska, Ewa and Lars Kristensen, editors. Marx at the Movies: Revisiting History, Theory and Practice. Palgrave Macmillan, 2014.

McCarthy, Thomas A. Ideals and Illusions: On Reconstruction and Deconstruction in Contemporary Critical Theory. MIT Press, 1991.

McDonald, Ronan. The Death of the Critic. Bloomsbury Academic, 2009.

Motion Picture Association of America (MPAA). "Theatrical Market Statistics", 2016. https:// www.mpaa.org/wp-content/uploads/2017/03/MPAA-Theatrical-Market-Statistics-2016_ Final.pdf.

Nussbaum. Martha. Not for Profit: Why Democracy Needs the Humanities. Princeton University Press, 2016.

Ollman, Bertell.Dance of the Dialectic: Steps in Marx's Method. University of Illinois Press, 2003. 
Peters, Michael, Mark Olssen, and Colin Lankshear. "Introduction: Futures of Critical Theory-Dreams of Difference", in Futures of Critical Theory: dreams of difference. Michael Peters et al. Rowman \& Littlefield, 2003.

Pop, Doru. The "Double Mirror" in James Cameron's Avatar - Philosophy, Ecology, Ideology and Ontology on Pandora, in Ekphrasis. Images, Cinema, Media, Theory, issue 1/ 2009.

Pop, Doru. "Mad Max - Spare-Parts Heroes, Recycled Narratives, Reused Visualities and Recuperated Histories". Caietele Echinox 29/ 2015.

Popper, Karl R. Conjectures and Refutations: The Growth of Scientific Knowledge. Harper \& Row, 1968.

Rodowick, David Norman. Elegy for Theory. Harvard University Press 2014

Rush, Zachariah. Cinema and Its Discontents: The Dialectical Nature of Character. McFarland, 2016.

Shepherd Jessica. 'Stop funding Mickey Mouse degrees, says top scientist'. The Guardian, 10 February, 2010. https://www.theguardian.com/education/2010/feb/10/stop-fundingmickey-mouse-degrees

Sloterdijk, Peter. Critique of Cynical Reason. Translated by Michael Eldred. University of Minnesota Press, 2001 (first German edition 1983).

Der Spiegel. 'The Islamist Mouseketeers. Hamas Mickey Mouse Teaches Jihad'. May 09 2007. http://www.spiegel.de/international/zeitgeist/the-islamist-mouseketeers-hamasmickey-mouse-teaches-jihad-a-481940.html.

Stalin, Joseph. Dialectical and Historical Materialism. (3rd Indian Edition.). Burmon Pub. House, 1943.

Thompson, Kristin. Breaking the Glass Armor: Neoformalist Film Analysis. Princeton, NJ: Princeton University Press, 1988.

Urwand, Ben. The Collaboration. Hollywood's Pact with Hitler. Belknap Press of Harvard University Press, 2015.

Vighi, Fabio. Critical Theory and Film: Rethinking Ideology through Film Noir. Continuum, 2012.

Wasko, Janet. Understanding Disney: The Manufacture of Fantasy. Polity Press, 2013.

Wexler, Philip ed. Critical Theory Now. The Falmer Press, 1991.

Wilkerson, William S., and Jeffrey Paris. New Critical Theory: Essays on Liberation. Rowman and Littlefield, 2001.

Žižek, Slavoj. The Sublime Object of Ideology. Verso, 1989

Žižek, Slavoj. The Fright of Real Tears: Krzysztof Kieślowski between Theory and Post-Theory. Reprinted ed. British Film Institute, 2009a.

Žižek, Slavoj. The Ticklish Subject: The Absent Centre of Political Ontology. The Essential Žižek. Verso, 2009b.

Žižek, Slavoj. The Parallax View. MIT Press, 2006.

Zornado, Joseph L. Inventing the Child: Culture, Ideology, and the Story of Childhood. Garland Publishing, 2001.

Zornado, Joseph L. Disney and the Dialectic of Desire. Palgrave Macmillan, 2017. 